RESEARCH ARTICLE

\title{
Nutrient Management Techniques for Organically Grown Finger Millet Somasundaram $E^{1}$, Ganesan $K^{1}$, Ganesh $R^{1}$, Sunitha $R^{1}$ and Udhaya Nandhini $D^{2}$ \\ ${ }^{1}$ Department of Sustainable Organic Agriculture,Tamil Nadu Agricultural University, Coimbatore-641 003 \\ ${ }^{2}$ Centre of Excellence in Sustaining Soil Health, Anbil Dharmalingam Agricultural College \&Research Institute, TNAU, Trichy - 620027
}

\begin{abstract}
Field experiments were conducted at TNAU, Coimbatore during 2019 and 2020 for developing organic nutrient package for finger millet (Ragi) using the variety $\mathrm{CO}(\mathrm{Ra}) 15$. Treatments included twelve combinations of weed compost, enriched vermicompost, enriched farmyard manure (EFYM) as soil application along with panchagavya, effective microbes (EM), vermiwash, egg

Received : $22^{\text {nd }}$ July, 2020

Revised : $18^{\text {th }}$ August, 2020

Accepted : $03^{\text {rd }}$ September, 2020 amino acid as foliar spray. The experiment was laid out in RBD with three replications. The results showed that application of enriched vermicompost @ 1t ha-1 applied in two equal splits on 25 and 40 DAT along with foliar application of egg amino acid @ 5\% on 30 and 45 DAT was found to be the best nutrient management package for organic finger millet based on the grain yield (2746 $\mathrm{kg} \mathrm{ha}^{-1}$ ). However the maximum net return (Rs. 31,477) and BCR of 1.94 was recorded under basal application of EFYM @ $750 \mathrm{~kg}$ ha ${ }^{-1}$ along with foliar spraying of EM @ 5\% on 30 and 45 DAT thus proving as an economically viable nutrient package for organic finger millet production.
\end{abstract}

Keywords: Finger millet; Organic practices; Enriched vermicompost; Manures; Effective Microbes.

\section{INTRODUCTION}

Modern agriculture practices rely on chemical fertilizers, which led to self-sufficiency in food grain production but also posed several new challenges. The productivity of most of the crops had been declining. Increased prices of chemical fertilizers and concerns about the sustainability of intensive cropping systems have led countries to promote organic materials as a source of nutrients for crops and as an amendment to improve soil properties. Organic farming minimizes the use of external inputs and aims at the optimization of crop productivity rather than its maximization through renewal and strengthening of ecological processes and functions of the farm ecosystem (Shukla et al., 2011).

Therefore the use of locally available agroinputs in agriculture by avoiding or minimizing the use of synthetic agrochemicals appears to be one of the feasible options to sustain the agricultural productivity. Various organic nutrient sources are available, which contain a good amount of major plant nutrients to produce comparable yield (Ghosh, 2005). The practices of organic cultivation vary with the availability of local resources of manures and their nutrient content, and as such, it is necessary to identify both the source and its quantity to meet the nutrient requirement of the crop. At the same time, the food habits of the consumers are changing rapidly. People have become more health-conscious.
Hence the demand for organic food products, especially nutricereals (millets), is on the rise.

Finger millet, commonly known as ragi (Eleusine coracana (L.) Gaertn.) is an essential small millet crop ranked third in India in area and production and has pride of place in having the highest productivity among the millets after sorghum and pearl millet. Tamil Nadu is one among the important states in the country cultivating finger millet, which contributes $7.24 \%$ to the area and $16.18 \%$ to the production. Ragi is a versatile crop with high nutrient profile of protein (6-8\%), fat (1.3\%), calcium (296 mg), carbohydrate (70-76\%), lysine (2.86\%), tryptophan $(1.39 \%)$ and methionine (2.86\%) (Aparna and Ansari, 2017). Hence an attempt was made to develop the organic nutrient management practices for finger millet under different types of manures and foliar nutrition.

\section{MATERIAL AND METHODS}

Field experiments for developing organic package of practices for finger millet (Ragi) using the variety $\mathrm{CO}(\mathrm{Ra}) 15$ were conducted at Eastern Block Farm, TNAU, Coimbatore during Kharif 2019 and 2020. The experimental site located in the western agro climatic zone of Tamil Nadu at $11^{\circ} \mathrm{N}$ latitude, $77^{\circ} \mathrm{E}$ longitude and at an altitude of $426.72 \mathrm{~m}$ above mean sea level. The soil of the experimental field was clay loam with a $\mathrm{pH}$ of 7.7 , $\mathrm{EC}$ of $0.82 \mathrm{dSm}^{-1}$ and organic carbon (OC) of $0.8 \%$. The experiment was laid out in a randomized block 
design with twelve treatments (Table 1 ) replicated thrice. Nursery sowing was done in raised beds and later transplanted at the spacing of $30 \times 15 \mathrm{~cm}$ in the main field with a gross plot size of $5 \mathrm{~m} \times 4 \mathrm{~m}$ under irrigated condition. Enriched FYM and vermicompost is prepared by using rock phosphate @10kg/ton of compost/FYM and biofertilizers (azophos) @ 2kg/ ton of compost/FYM were mixed and incubated for 60 days before applying to the field. For weed compost, weeds were collected and made into compost using silpaulin composting method. Enriched EM was prepared by using EM solution, jaggery and yeast. Egg amino acid was prepared by mixing equal parts of fish waste and jaggery fermented for a month time (Priyanka et al., 2019). Treatments were imposed as per the schedule. Five plants per plot were tagged for recording the growth and yield parameters. The economics of the system was worked out considering the prevailing cost of inputs and price of output. All the results were then analyzed statistically for drawing conclusion using analysis of variance (ANOVA) procedure (Gomez and Gomez, 1984).

\section{RESULTS AND DISCUSSION}

\section{Growth parameters}

\section{Plant height}

Plots treated with enriched vermicompost @ 1t ha $^{-1}$ in two equal splits on 25 and 40 DAT along with foliar spraying of egg amino acid @ 5\% on 30 and 45 DAT $\left(T_{8}\right)$ had recorded the maximum mean plant height $(112.7 \mathrm{~cm})$ compared to other treatments. This might be due to higher availability of nitrogen from enriched vermicompost as well as considerable amount of nutrients and amino acids from egg amino acid as stated by Priyanka et al. (2019). However it was comparable with split application of enriched vermicompost along with foliar spray of verminwash $\left(\mathrm{T}_{9}\right)(109.9 \mathrm{~cm})$.

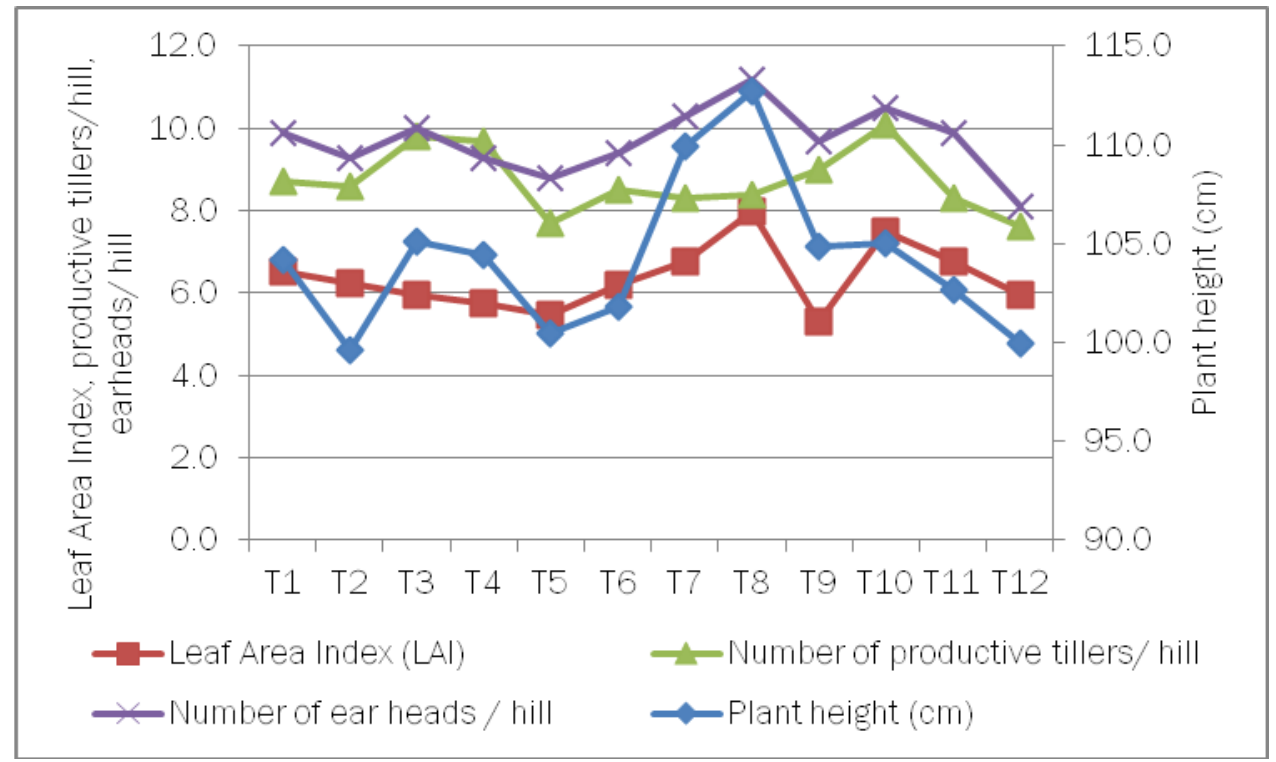

Figure 1. Effect of treatments on plant height, leaf area index, number of productive tillers/hill and number of ear heads/ hill of finger millet grown organically

The shortest plants $(99.6 \mathrm{~cm})$ were observed in plots applied with weed compost @ $5 \mathrm{t} \mathrm{ha}^{-1}$ in two equal splits on 25 and 40 DAT and foliar application of EM @ $5 \%$ on 30 and 45 DAT (T ${ }_{2}$ ) (Fig. 1).

\section{Leaf Area Index (LAI)}

The LAI was significantly higher (8.0) in plots applied with enriched vermicompost @ 1 t ha $^{-1}$ applied in two equal splits on 25 and 40 DAT along with foliar application of egg amino acid @ 5\% on 30 and 45 DAT $\left(\mathrm{T}_{8}\right)$. Enhanced availability of nitrogen from vermicompost and egg amino acid could have fecilitated for the increased LAI as evident from the research work of Priyanka et al. (2019). The lowest
LAI of 5.30 was noted in plots, which received EFYM @ $750 \mathrm{~kg} / \mathrm{ha}$ as basal along with foliar application of panchagavya @ 3\% on 30 and 45 DAT ( $T_{9}$ ) (Fig. 1).

\section{Yield parameters}

\section{Productive tillers}

The mean number of productive tillers per hill was maximum (10.1) in plots applied with EFYM @ $750 \mathrm{~kg} \mathrm{ha}^{-1}$ as basal along with foliar spray of EM @ $5 \%$ on 30 and 45 DAT $\left(T_{10}\right)$. This might be due to enhanced NPK nutrition by EM along with farmyard manure as reported by Javaid and Bajwa (2011) in mung bean. Whereas results are in contrast with findings of Iwaishi (2001) who reported that the 
application of EM along with organic manures has caused longer tillers rather than more number of tillers per plant. However EFYM applied with EM was comparable with all the weed compost applied plots irrespective of foliar sprays. Lower number of productive tillers per hill (7.6) was noted in plots treated with EFYM @ 750 kg/ha as basal along with foliar application of egg amino acid @ 5\% on 30 and 45 DAT $\left(T_{12}\right)$ (Figure 1).

Table 1.Treatment details

\begin{tabular}{|c|c|c|}
\hline $\mathrm{T}_{1}$ & : & Weed compost @ 5t/ha in two equal splits on 25 and 40 DAT + Foliar application of panchagavya @ 3\% on 30 and 45 DAT \\
\hline $\mathrm{T}_{2}$ & : & Weed compost @ 5t/ha in two equal splits on 25 and 40 DAT + Foliar application of EM @ 5\% on 30 and 45 DAT \\
\hline $\mathrm{T}_{3}$ & : & Weed compost @ 5t/ha in two equal splits on 25 and 40 DAT + Foliar application of vermiwash @ 5\% on 30 and 45 DAT \\
\hline $\mathrm{T}_{4}$ & : & Weed compost @ 5t/ha in two equal splits on 25 and 40 DAT + Foliar application of egg amino acid @ 5\% on 30 and 45 DAT \\
\hline $\mathrm{T}_{5}$ & : & Enriched vermicompost @ 1t/ha in two equal splits on 25 and 40 DAT+ Foliar application of panchagavya @ $3 \%$ on 30 and 45 DAT \\
\hline $\mathrm{T}_{6}$ & : & Enriched vermicompost @ 1t/ha in two equal splits on 25 and 40 DAT+ Foliar application of EM @ 5\% on 30 and 45 DAT \\
\hline $\mathrm{T}_{7}$ & : & Enriched vermicompost @ 1t/ha in two equal splits on 25 and 40 DAT+ Foliar application of vermiwash @ 5\% on 30 and 45 DAT \\
\hline $\mathrm{T}_{8}$ & : & Enriched vermicompost @ 1t/ha in two equal splits on 25 and 40 DAT+ Foliar application of egg amino acid @ $5 \%$ on 30 and 45 DAT \\
\hline $\mathrm{T}_{9}$ & : & EFYM @ 750 kg/ha as basal+ Foliar application of panchagavya @ 3\% on 30 and 45 DAT \\
\hline $\mathrm{T}_{10}$ & : & EFYM @ 750 kg/ha as basal+ Foliar application of EM @ 5\% on 30 and 45 DAT \\
\hline $\mathrm{T}_{11}$ & : & EFYM @ 750 kg/ha as basal+ Foliar application of vermiwash @ 5\% on 30 and 45 DAT \\
\hline $\mathrm{T}_{12}$ & : & EFYM @ 750 kg/ha as basal+ Foliar application of egg amino acid @ 5\% on 30 and 45 DAT \\
\hline
\end{tabular}

\section{Ear heads per hill}

The mean number of productive ear heads per hill was maximum (11.2) in plots applied with enriched vermicompost @ 1t ha-1 applied in two equal splits on 25 and 40 DAT along with foliar application of egg amino acid @ 5\% on 30 and 45 DAT $\left(T_{8}\right)$. However, it was comparable with basal application of EFYM along with foliar spray of EM ( $\left.T_{10}\right)(10.5)$ and split application of enriched vermicompost along with foliar spray of vermiwash (10.3). The lowest ear heads per hill (8.1) was noted in plots treated with EFYM @ 750 kg ha-1 as basal along with foliar application of egg amino acid @ 5\% on 30 and 45 DAT ( $T_{12}$ ) (Fig. 1).

Table 2. Effect of treatments on ear head length and ear head weight of finger millet

\begin{tabular}{|c|c|c|c|c|c|c|}
\hline \multirow[t]{2}{*}{ Treatments } & \multicolumn{3}{|c|}{ Ear head length (cm) } & \multicolumn{3}{|c|}{ Ear head weight (g) } \\
\hline & $2018-19$ & $2019-20$ & Mean & $2018-19$ & $2019-20$ & Mean \\
\hline $\mathrm{T}_{1}$ - Weed compost @ 5t/ha + Panchagavya @ 3\% & 8.9 & 10.2 & 9.6 & 11.5 & 9.8 & 10.6 \\
\hline $\mathrm{T}_{2}$ - Weed compost @ 5t/ha + EM @ 5\% & 8.8 & 10.4 & 9.6 & 12.7 & 9.6 & 11.1 \\
\hline $\mathrm{T}_{3}$ - Weed compost @ 5t/ha + Vermiwash @ 5\% & 8.5 & 10.1 & 9.3 & 12.1 & 9.8 & 11.0 \\
\hline $\mathrm{T}_{4}$ - Weed compost @ 5t/ha + Egg amino acid @ 5\% & 9.3 & 10.0 & 9.6 & 11.3 & 9.7 & 10.5 \\
\hline $\mathrm{T}_{5}$. Enriched vermicompost @ 1t/ha + Panchagavya @ 3\% & 10.0 & 9.9 & 9.9 & 9.7 & 10.9 & 10.3 \\
\hline $\mathrm{T}_{6}$ - Enriched vermicompost @ 1t/ha + EM @ 5\% & 9.8 & 10.2 & 10.0 & 8.8 & 10.7 & 9.8 \\
\hline $\mathrm{T}_{7}$ - Enriched vermicompost @ 1t/ha + Vermiwash @ 5\% & 9.6 & 9.8 & 9.7 & 11.5 & 10.5 & 11.0 \\
\hline $\mathrm{T}_{8}$ - Enriched vermicompost @ 1t/ha + Egg amino acid @ 5\% & 9.4 & 10.0 & 9.7 & 11.8 & 11.4 & 11.6 \\
\hline T. - EFYM @ 750 kg/ha as basal+ Panchagavya @ 3\% & 9.0 & 9.8 & 9.4 & 9.7 & 8.7 & 9.2 \\
\hline $\mathrm{T}_{10}-\mathrm{EFYM} @ 750$ kg/ha as basal+ EM @ 5\% & 9.4 & 10.8 & 10.1 & 8.3 & 12.1 & 10.2 \\
\hline $\mathrm{T}_{11}$ - EFYM @ 750 kg/ha as basal+ Vermiwash @ 5\% & 8.4 & 9.7 & 9.0 & 9.6 & 10.7 & 10.2 \\
\hline $\mathrm{T}_{12}$ - EFYM @ 750 kg/ha as basal+ Egg amino acid @ 5\% & 8.4 & 9.8 & 9.1 & 11.4 & 10.8 & 10.6 \\
\hline SEd & 0.40 & 0.71 & - & 0.79 & 0.69 & - \\
\hline $\mathrm{CD}(0.05)$ & 0.81 & 1.43 & - & 1.59 & 1.40 & - \\
\hline
\end{tabular}

\section{Ear head length}

Ear head length was influenced significantly by the application of treatments (Table 2). The mean ear head length was maximum $(10.1 \mathrm{~cm})$ in plots applied with EFYM @ $750 \mathrm{~kg} \mathrm{ha}^{-1}$ as basal along with foliar spray of EM @ $5 \%$ on 30 and 45 DAT $\left(T_{10}\right)$.

$107|7-9| 250$ 
However, it was comparable with all the enriched vermicompost applied treatments. Balanced release of macro and micronutrients from EFYM as reported by Poonam Kumari Yadav et al., (2019) accompanied with enhanced nutrition uptake stimulated by foliar application of EM would have caused the effect. Similar kind of observation was also made by Shinji Iwaishi (2001) where the EM treatment was found to be beneficial in increasing the ear length of rice. The shortest ear head $(9.0 \mathrm{~cm})$ was observed in plots treated with EFYM @ $750 \mathrm{~kg} \mathrm{ha}^{-1}$ as basal along with foliar application of vermiwash @ 5\% on 30 and $45 \operatorname{DAT}\left(\mathrm{T}_{11}\right)$.

\section{Ear head weight}

Ear head weight was found to deviate significantly among the treatments (Table 2). The maximum mean ear head weight (11.6 g) was observed in plots treated with enriched vermicompost @ 1t ha $^{-1}$ applied in two equal splits on 25 and 40 DAT along with foliar application of egg amino acid @ $5 \%$ on 30 and 45 DAT $\left(T_{8}\right)$. The higher ear head weight was ascribed to synergetic effect of enriched vermicompost and egg amio acid. This was also supported by Basavarajappa et al., (2002) who also observed the increased earhead weight in foxtail millet treated with enriched manures. However all the treatments are comparable with each other except EFYM@750 kg ha-1 as basal along with foliar application of panchagavya @ 3\% on 30 and 45 DAT (9.2).

\section{Grain yield}

Significantly higher grain yield of $2563 \mathrm{~kg} \mathrm{ha}{ }^{-1}$ and $2928 \mathrm{~kg} \mathrm{ha}^{-1}$ was recorded in plots treated with enriched vermicompost @ 1t ha-1 applied in two equal splits on 25 and 40 DAT along with foliar application of egg amino acid @ 5\% on 30 and 45 DAT $\left(\mathrm{T}_{8}\right)$ during both the years of study. The rich source of NPK in the vermicompost compared to other manures along with the presence of plant hormones like auxins, gibberellins, cytokinins and enzymes like phosphatase, cellulase would have enhanced the plant growth and overall yield.

Table 3. Effect of treatments on yield of finger millet grown organically

\begin{tabular}{|c|c|c|c|c|c|c|}
\hline \multirow{2}{*}{ Treatments } & \multicolumn{3}{|c|}{ Grain yield $(\mathrm{kg} / \mathrm{ha})$} & \multicolumn{3}{|c|}{ Straw yield (kg/ha) } \\
\hline & $2018-19$ & $2019-20$ & Mean & $2018-19$ & $2019-20$ & Mean \\
\hline T & 2281 & 2730 & 2506 & 5234 & 6210 & 5722 \\
\hline T. Weed compost @ 5t/ha + EM @ 5\% & 2328 & 2324 & 2326 & 5697 & 5489 & 5593 \\
\hline $\mathrm{T}_{3}$ - Weed compost @ 5t/ha + Vermiwash @ 5\% & 1906 & 2614 & 2260 & 4813 & 6733 & 5773 \\
\hline T - Weed compost @ 5t/ha + Egg amino acid @ 5\% & 1938 & 2412 & 2175 & 4875 & 6199 & 5537 \\
\hline $\mathrm{T}_{5}$ - Enriched vermicompost @ 1t/ha + Panchagavya @ 3\% & 1406 & 2397 & 1902 & 4638 & 5022 & 4830 \\
\hline T6 - Enriched vermicompost @ 1t/ha + EM @ 5\% & 2009 & 2831 & 2420 & 4891 & 7263 & 6077 \\
\hline $\mathrm{T}_{7}$ - Enriched vermicompost @ 1t/ha + Vermiwash @ 5\% & 2016 & 2864 & 2440 & 4922 & 5609 & 5266 \\
\hline T - Enriched vermicompost @ 1t/ha + Egg amino acid @ 5\% & 2563 & 2928 & 2746 & 5844 & 5949 & 5896 \\
\hline T. - EFYM @ 750 kg/ha as basal+ Panchagavya @ 3\% & 1366 & 1632 & 1499 & 4275 & 6385 & 5330 \\
\hline $\mathrm{T}_{10}$ - EFYM @ 750 kg/ha as basal+ EM @ 5\% & 2344 & 2890 & 2617 & 5713 & 4963 & 5338 \\
\hline T & 2391 & 2282 & 2337 & 5725 & 4536 & 5131 \\
\hline $\mathrm{T}_{12}$ - EFYM @ 750 kg/ha as basal+ Egg amino acid @ 5\% & 2219 & 2688 & 2454 & 5141 & 5548 & 5344 \\
\hline SEd & 32.10 & 39.97 & - & 79.24 & 94.45 & - \\
\hline CD (0.05) & 65.30 & 81.31 & - & 161.23 & 192.16 & - \\
\hline
\end{tabular}

Significant increase in yield of finger millet treated with vermicompost was also reported by Prabudoss et al. (2014). Quick absorption and assimilation of more nitrogen, phosphorus, potassium and micro nutrients present in the egg amino acid applied through foliar spray would have increased the photosynthetic activity which in turn resulted in higher yield (Priyanka et al., 2019). This could also be due to synergistic and cumulative effect of enriched vermicompost and foliar applied egg amino acid which might have exerted a marked influenced on the yield of transplanted finger millet. The next higher mean grain yield of $2617 \mathrm{~kg} \mathrm{ha}^{-1}$ was observed in EFYM @ $750 \mathrm{~kg} \mathrm{ha}^{-1}$ as basal with foliar application of EM @ 5\% on 30 and 45 DAT $\left(T_{10}\right)$ applied plots. The lowest grain yield (1499 kg ha-1) was noted in plots treated with EFYM @ $750 \mathrm{~kg} \mathrm{ha}^{-1}$ as basal along with foliar application of panchagavya @ $3 \%$ on 30 and 45 DAT $\left(\mathrm{T}_{9}\right)$ (Table 3 ).

\section{Straw yield}

The effect of treatments on straw yield was given in table 3.The mean dry straw yield was more (6077 $\mathrm{kg} \mathrm{ha}^{-1}$ ) in plots treated with enriched vermicompost @ 1t ha ${ }^{-1}$ in two splits on 25 and 40 DAT along with foliar application of EM @ 5\% on 30 and 45 DAT $\left(\mathrm{T}_{6}\right)$. 
However it was comparable with $\mathrm{T}_{8}$ (enriched vermicompost @ 1t ha-1 applied in two equal splits on 25 and 40 DAT along with foliar application of egg amino acid @ 5\% on 30 and 45 DAT combination) of $5896 \mathrm{~kg} \mathrm{ha}^{-1}$. Significant increase in shoot biomass by foliar spray of EM was also reported by Arshad Javaid (2006). Diverse presence of microorganisms in the EM solution stimulates crop growth by increasing photosynthesis, producing bioactive substances such as hormones and enzymes, amino acids, polysaccharides, nucleic acids and sugars (Higa,2000; Hussain et al., 2002). This had eluded the crop to perform with better growth and resulting in more straw yield. The lowest straw yield of $4830 \mathrm{~kg} \mathrm{ha}^{-1}$ was noted in plots applied with enriched vermicompost @ 1 t ha ${ }^{-1}$ in two splits on 25 and 40 DAT followed by foliar application of panchagavya @ 3\% on 30 and 45 DAT $\left(\mathrm{T}_{5}\right)$.

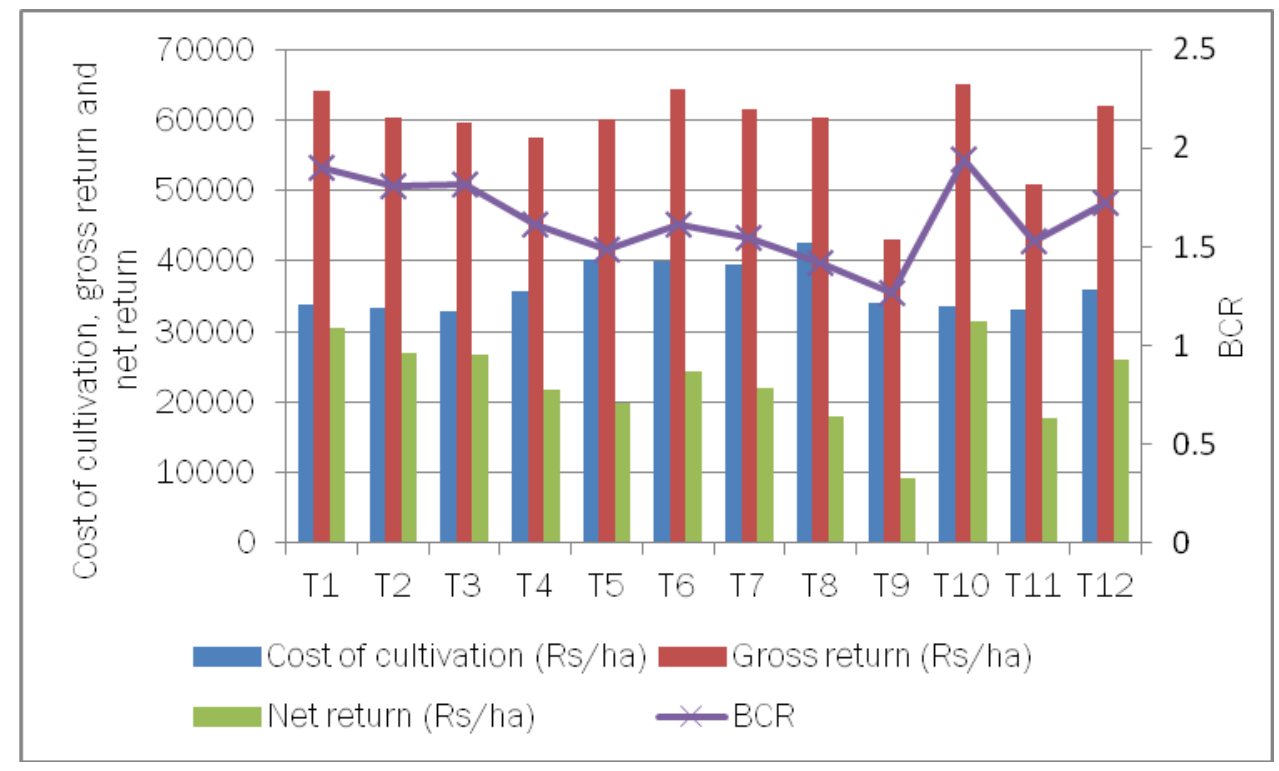

Figure 2. Effect of treatments on economics of finger millet grown organically

\section{Economics}

\section{Cost of cultivation}

Among the treatments, the per hectare cost of cultivation was highest (Rs. 42465) in plots treated with enriched vermicompost @ 1t ha ${ }^{-1}$ in two splits on 25 and 40 DAT along with foliar application of egg amino acid @ 5\% on 30 and 45 DAT $\left(T_{8}\right)$. This was due to the cost incurred for the production of enriched vermicompost and egg amino acid was higher compared to other treatments. The lowest per hectare cost of cultivation (Rs. 32885) was noted in weed compost @ 5t/ha in two equal splits on 25 and 40 DAT along with foliar application of vermiwash @ 5\% on 30 and 45 DAT applied plots ( $\left.T_{3}\right)$ (Fig. 2).

\section{Gross return}

The gross return was differed with the treatments and was worked out based on the prevailing market prices without any premium (Fig. 2). Gross return per hectare was highest (Rs. 65082) in plots applied with EFYM @ $750 \mathrm{~kg} \mathrm{ha}^{-1}$ as basal along with foliar spray of EM @ 5\% on 30 and 45 DAT $\left(T_{10}\right)$. Lower gross returns of Rs. 43158 was noted in plots applied with EFYM @ $750 \mathrm{~kg} \mathrm{ha}^{-1}$ with foliar application of panchagavya @ 3\% on 30 and 45 DAT $\left(\mathrm{T}_{9}\right)$.

\section{Net Return}

The plots applied with EFYM @ 750 kg ha-1 along with foliar spraying of EM @ 5\% on 30 and 45 DAT $\left(T_{10}\right)$ has fetched the highest net return per ha (Rs. 31,477 ) followed by $T_{1}$ (weed compost @ $5 \mathrm{t} \mathrm{ha}^{-1}$ in two equal splits on 25 and 40 DAT along with foliar application of panchagavya @ 3\% on 30 and 45 DAT) of Rs.30,400. Lower net return of Rs. 9193 was observed in EFYM @ $750 \mathrm{~kg} \mathrm{ha}^{-1}$ as basal along with foliar application of panchagavya @ 3\% on 30 and 45 DAT $\left(\mathrm{T}_{9}\right)$ (Fig. 2).

\section{Benefit Cost Ratio (BCR)}

The benefit cost ratio computed from the study is furnished in Figure 2, which revealed that the maximum BCR of 1.94 was associated with the treatment basal application of EFYM @ $750 \mathrm{~kg} \mathrm{ha}^{-1}$ along with foliar spraying of EM @ 5\% on 30 and 45 DAT $\left(\mathrm{T}_{10}\right)$. Higher gross return and lower cost of cultivation has resulted in maximum BCR. Lower BCR (1.27) was observed in plots treated with EFYM @ $750 \mathrm{~kg} \mathrm{ha}^{-1}$ as basal along with foliar application of panchagavya @ 3\% on 30 and 45 DAT $\left(\mathrm{T}_{9}\right)$.

\section{CONCLUSION}

Nutrient management package for organic finger 
millet production was developed through this study. Application of enriched vermicompost @ 1t ha-1 in two equal splits on 25 and 40 DAT along with foliar application of egg amino acid @ 5\% on 30 and 45 DAT was found to be the best nutrient management package for organic finger millet based on the grain yield $\left(2746 \mathrm{~kg} \mathrm{ha}^{-1}\right)$. However the maximum net return (Rs. 31,477) and BCR of 1.94 was recorded under basal application of EFYM @ $750 \mathrm{~kg} \mathrm{ha}^{-1}$ along with foliar spraying of EM @ 5\% on 30 and 45 DAT thus proving as an economically viable package for organic finger millet production even under no premium price situation.

\section{REFERENCES}

Aparna, K. and Z. G. Ansari. 2017. Evaluation of rag genotypes on growth parameters and physiological attributes under kharif rainfed conditions. Int. J. of Chemical Studies, 5(6): 1899-1901

Arshad Javaid and Rukhsana Bajwa. 2011. Effect of effective microorganism application on crop growth, yield, and nutrition in Vigna radiata(L.) Wilczek in different soil amendment systems. Communications in Soil Sci. and Plant Analysis, 42: 2112-2121.

Basavarajappa R., Prabhakar, A.S. and S.I. Halikatti. 2002. Effect of tillage practices, organics, nitrogen levels and their interaction on yield and economics of foxtail millet during kharif. Karnataka J. Agric. Sci., 15(3): 485-490.

Ghosh, A. 2005. Organic rice farming technology development and its feasibility. Indian Farming., 55(9): 4-7.
Gomez, K.A. and A. A. Gomez. 1984. Statistical procedures for agricultural research. $2^{\text {nd }}$ edn, John Wiley and Sons, New York.

Higa, T. 2000. What is EM technology ?. EM World J., 1: 1-6.

Hussain, T., Anjum, A.D. and J. Tahir. 2002. Technology of bene cial microorganisms. Nature Farming and Environment, 3: 1-14.

Javaid, A. 2006. Foliar application of effective microorganisms as an alternative fertilizer for pea. Agron. for Sustainable Development, 26: 257-262.

Poonam Kumari Yadav, Rajhans Verma, Bamboriya, J.K., Suresh Yadav and Rajesh C.Jeeterwal. 2019. Response of pearl millet [Pennisetum glaucum L. (R. Br.)] to integrated nitrogen management. Int.J.Curr.Microbiol.App.Sci., 8(2): 429-437.

Prabudoss V., Jawahar, S., Shanmugaraja, P. and K. Dhanam. 2014. Effect of integrated nutrient management on growth,yield and economics of transplanted kodo millet. European Journal of Biotechnology and Bioscience, 1(4): 30-33.

Priyanka, B., Ramesh, T., Rathika, S. and P. Balasubramaniam. 2019. Foliar application of fish amino acid and egg amino acid to improve the physiological parameters of rice. Int. J. Curr. Microbiol. App. Sci., 8(2): 3005-3009.

Shinji Iwaishi. 2001. Effect of organic fertilizer and effective microorganisms on growth, yield and quality of paddy-rice varieties. J. Crop Production, 3:1, 269-273.

Shukla, A., Patel B.R., Patel A.N. and A.R. Patel. 2011. Organic farming for sustainable agriculture. Kisan World, 38(3): 39-42. 